\title{
In situ swimming speeds of the late pelagic larvae of some Indo-Pacific coral-reef fishes
}

\author{
Jeffrey M. Leis*, Brooke M. Carson-Ewart
}

Fish Section, Division of Vertebrate Zoology and Centre for Biodiversity and Conservation Research, Australian Museum, 6 College Street, Sydney, New South Wales 2000, Australia

\begin{abstract}
Swimming speeds of the late-stage, pelagic larvae of coral-reef fishes were measured in situ near Lizard Island on Australia's Great Barrier Reef, and Rangiroa Atoll, Tuamotu Islands, French Polynesia during 1995-96. Larvae were captured with light traps and crest nets, and released individually in open water. They were then followed by SCUBA divers, normally for $10 \mathrm{~min}$, and their speed was measured with a modified plankton-net flow meter and a stop watch. Swimming speeds of 260 larvae of 50 species in 15 families of mostly perciform reef fishes are presented. Most measurements were for pomacentrids ( 8 genera, 16 species, 127 individuals), apogonids $(1$ genus, 25 species, 18 individuals), chaetodontids ( 3 genera, 8 species, 49 individuals), lethrınds ( 1 genus, -4 species, 11 individuals), nemipterids (1 genus, 2 species, 10 individuals), serranids (2 genera, 2 species, 14 individuals) and acanthurids ( 2 genera, $\sim 4$ species, 13 individuals). Numbers of individuals per species ranged from 1 to 25 . Speeds were remarkably high for such small fishes $(0.7$ to $5.5 \mathrm{~cm})$. Average speed was $20.6 \mathrm{~cm}$ $\mathrm{s}^{-1}$ (range 2 to 65 ), or 13.7 body lengths $\mathrm{s}^{-1}$ (range 2 to 34 ). SE for species with $\mathrm{n}>4$ ranged from 0.8 to $5.3 \mathrm{~cm} \mathrm{~s}^{-1}$ ( 4.1 to $25.0 \%$ of mean speed), but speed of the fastest individual of each species averaged $144 \%$ of mean speed. A taxonomic component was evident, with apogonids the slowest ( 2 to $\left.13 \mathrm{~cm} \mathrm{~s}^{-1}\right)$, followed by nemipterids $\left(10 \mathrm{~cm} \mathrm{~s}^{-1}\right)$. Speed of pomacentrids and chaetodontids varied widely among species ( 7 to $35 \mathrm{~cm} \mathrm{~s}^{-1}$ ), whereas acanthurids, lethrinids and serranids were fast $\left(19\right.$ to $\left.55 \mathrm{~cm} \mathrm{~s}^{-1}\right)$. Except for apogonids and nemipterids, nearly all species had mean swimming speeds greater than average ambient current speeds in the Lizard Island area. Mean speed was positively correlated with size (slope $8.2, r^{2}=0.43$ ) when all taxa were included, but was not correlated with size for the Pomacentridae and Chaetodontidae when each were considered alone. The speeds reported here combined with data on swimming endurance recently reported by Stobutzki \& Bellwood (1997; Mar Ecol Prog Ser 149:35-41) reveal remarkable swimming abilities for late-stage pelagic larvae of coral-reef fishes which could elther greatly enhance dispersal or eliminate it.
\end{abstract}

KEY WORDS: Fish larvae Swimming speed Coral reefs Dispersal Pelagic speed

\section{INTRODUCTION}

Like most marine animals, the fishes of coral-reefs have a complex life history including a pelagic larval stage with great potential for dispersal, and a much more sedentary adult stage closely associated with the reef (Leis 1991). It is thought that most dispersal takes place during the pelagic larval stage, and it is clear that the majority of mortality takes place between spawning and settlement (Sale 1991). Information on the biology of the pelagic stage of reef fishes has been

•E-mail: jeffl@amsg.austmus.gov.au slow to accumulate, and most of what is available concerns taxonomy and distribution. An understanding of any aspect of behaviour during the pelagic stage has been especially difficult to obtain. Laboratory studies have been hindered by the difficulty of rearing reef fishes and the relatively large volumes of water that are required as the larvae grow and become more active. Field observations of the behaviour of pelagic reef-fish larvae are largely limited to anecdotal observations. Direct observation is made difficult by the very dispersed and dilute nature of larval distributions and the effective adaptations for camouflage in the pelagic environment possessed by the larvae (Leis et al. 1996). 
Knowledge of the swimming speed of the larvae and other presettlement stages of reef fishes during the pelagic stage is important for an understanding of the ecology and dispersal of this stage. For example, only if the swimming capabilities of the larvae are known can we begin to understand to what extent these small fishes have control of their distribution. It is widely acknowledged that such larvae cannot be regarded as passive particles, but how far along the planktonic to nektonic continuum they are located is unknown. Information on temperate species, much of it derived from laboratory studies, indicates that fish larvae are weak swimmers (Blaxter 1986, Miller et al. 1988). However, Stobutzki \& Bellwood (1994, 1997) have shown that late-stage coral-reef fish larvae in a laboratory swimming chamber (flume) are capable of high speeds and surprisingly large ambits. Furthermore, Leis et al. (1996) estimated some coral-reef fish larvae swam as fast as $30 \mathrm{~cm} \mathrm{~s}^{-1}$ in the field. Our observations in situ, presented here, confirm that speeds as high as reported by Stobutzki \& Bellwood also occur in the field where the larvae themselves choose the speeds at which they swim. This paper provides unique information on the in situ swimming speed of the late pelagic stages of reef fishes. This information was obtained by the use of a recently developed methodology for making behavioural observations on the pelagic stages of reef fishes in open water (Leis et al. 1996).

Nomenclature of the pelagic stages of coral-reef fishes varies among authors. The fishes we studied were near the end of the pelagic stage and were just about to settle. Depending on the species and the author, these fishes might be considered larvae, postlarvae, prejuveniles, presettlement stages, or pelagic juveniles. The important point for our study is that they were still pelagic, and we refer to them all as larvae for convenience. For most species, this is consistent with the nomenclature of Leis \& Trnski (1989).

\section{METHODS}

The methods used here generally follow those of Leis et al. (1996). Late-stage larvae of reef fishes were captured by light trap [in the Great Barrier Reef, Australia (GBR)] or by crest nets fixed in the flow from ocean to lagoon in a hoa [shallow reef-flat channel, in Rangiroa, Tuamotu Islands, French Polynesia (Poly)\}. A single specimen, the ephippidid Platax pinnatus, was captured by hand in open water, where it seemed to be mimicking a flatworm. These methods provide individuals near the end of the pelagic period which are generally competent to sett]e (Doherty 1987, Choat et al. 1993, Dufour 1994). For most species there is little variation in size at this stage. Most individuals have a full complement of fin rays, and many are scaled. We refer to them as larvae not because they are incompletely developed, but because in most taxa they retain specialisations for pelagic life, such as head spination or elongate, ornamented fin spines (Leis \& Trnski 1989).

The larvae, in a large container of sea water, were taken to open water by boat. They were then released one at a time by a team of SCUBA divers. One of the divers (the observer) concentrated on keeping the released larva in sight and followed it at a distance of 1 to $3 \mathrm{~m}$, depending on the visibility of the fish. The other diver followed close behind the first and made observations on time elapsed, depth, swimming direction (using a compass) and distance travelled (using a calibrated, plankton-net flow meter in a hand-held bracket; Fig. 1). The bracket-mounted meter was calibrated by swimming it over a $20 \mathrm{~m}$ course at least 5 times in opposite directions at each of 25,50 and $100 \mathrm{~cm} \mathrm{~s}^{-1}$. The mean calibration at these speeds differed from the most extreme by only $4 \%$, so the mean value was used.

Individual larvae were followed only once. With the information on distance travelled and time, speed could be calculated. Each released fish was normally followed for $10 \mathrm{~min}$, so most of the speeds reported here are average speeds for 10 min periods. However, some were followed for as little as $2 \mathrm{~min}$. Typically, a third person in a small $(<5 \mathrm{~m}, 25 \mathrm{hp}$ ) support boat would circle the divers' bubbles at 20 to $30 \mathrm{~m}$ radius. However, on some occasions, the boat was anchored with the motor turned off.

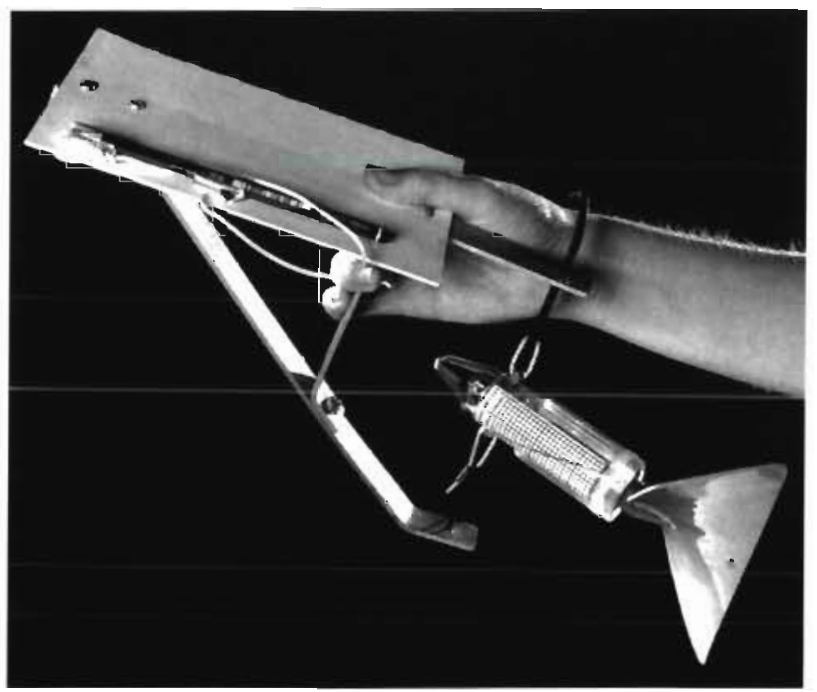

Fig. 1. Flowmeter console used to measure distance travelled. Meter was a calibrated General Oceanics Model $2030 \mathrm{R}$ with a low-speed rotor. Note underwater slate on top of bracket. Console was held by hand out in front of the second diver during in situ measurements of swimming speed 
Although the larvae were certainly aware of the presence of the divers, most species were amenable to this approach. By this, we mean they showed no apparent concern over the 2 divers, undertook no evasive manoeuvres, frequently fed, or examined potential food particles, and often attempted to shelter near the observer when potential predators appeared. Behaviour of late pelagic larvae was markedly different when they were actively pursued by divers for capture (e.g. for voucher specimens) or by predators. Finally, in other work, where we released larvae near reefs using the same methods and observed settlement behaviour, larvae swam slower over the reef than in open water and carefully examined potential settlement sites, sometimes settling, but sometimes rejecting them, and returned to the pelagic environment (unpubl. data). This indicates they were not trying to escape the divers. Larvae certainly did not increase speed with time in response to the following divers. This was taken as evidence that the fish were not stressed by the presence of the divers and the normal 'following procedure', and behaved naturally. We included data here only for fish that generally ignored the divers and swam in an apparently normal way. A few species frequently stopped, turned, faced the divers and hovered (e.g. tetraodontids), others would do little more than sink steeply to the bottom (e.g. Pomacentrus amboinensis), and some were very attracted to the divers and apparently tried to settle on them (e.g most blenniids and some holocentrids). For these taxa, only the few individuals that did not behave in this way were included in our study, but we note which taxa these were. In otherwise 'normal' species, some individuals would act in a decidedly nonnormal way, losing equilibrium as if damaged, or persisting in attempts to settle on the divers. Data from such individuals were excluded. A high proportion of individuals of the butterfly fish Chelmon rostratus swam on their sides, rather than in a more conventional orientation, for portions of the observation session. As these fish seemed otherwise normal and continued to swim strongly, we included swimming speed data from them.

For some taxa, we had difficulty obtaining swimming speed measurements. Partly, this was due to rarity or absence of these taxa in our collections due to gear selectivity (e.g. ephippidids, labrids, scarids). However, behavioural differences among taxa and individuals were more of a problem. Consequently, we were able to present only limited data on some taxa.

Swimming speed observations were made in the vicinity of Lizard Island, northern GBR, in the lagoon of the GBR, and at Poly. In most cases, water depth was 20 to $40 \mathrm{~m}$, but some measurements were made in shallower water, and a few were made in the open ocean off Poly over depths of $>300 \mathrm{~m}$. Larvae were never followed deeper than $20 \mathrm{~m}$. Most release points were in open water with no substrate in view. However, some were within sight of a reef. Data from these near-reef releases were excluded if the fish swam over the reef or made an effort to examine the bottom or settle. Lizard Island data were gathered in NovemberDecember 1995 and 1996 and January-February 1996. Water temperatures were 25.5 to $31.0^{\circ} \mathrm{C}$ during these periods (L. Vail pers. comm.). Poly data were gathered in June 1996. Water temperatures in the hoa are close to those in the ocean and were 24 to $28^{\circ} \mathrm{C}$ during this time (A. Lo-Yat pers. comm.).

Most larvae were identifiable in the field. Others were identified from larvae recaptured at the end of the observation period. In some cases, specimens of uncertain identity could not be captured at the end of the observation, or if captured could not be identified to species with confidence. These are indicated with a '?'. Where we use spp., we are uncertain of species identification, but are reasonably certain more than 1 species is involved. In some cases, some of the individuals could be identified, or the possibilities limited to a few species. These include the following: Apogon spp. - 'unstriped' spp such as fragilis and coccineus of similar larval morphology and size: called Apogon 'blackhead' by Leis et al. (1996); Lethrinus spp.includes at least L. genivittatus and variegatus; Scolopsis spp. - most are bilineatus, but a second, unidentified species is present; Dischistodus spp. - most, if not all, are D. prosopotaenia; Chromis atripectoralis-may include C. viridis; Neopomacentrus cyanomos? - may include $N$. bankieri; and Ptereleotris spp. (Poly)heteroptera and/or microlepis. Carapidid larvae of the Tribe Carapini (genera Carapus and Encheliophis) generally cannot be identified past the level of Tribe (Markle \& Olney 1990). Therefore, our carapidid larva was identified as Carapini.

Speed is expressed in $\mathrm{cm} \mathrm{s}^{-1}$ or in body lengths $\mathrm{s}^{-1}$ $\left(B L ~^{-1}\right)$. A 'family average' is the average of the mean speeds of each of the included species. Size of larvae is standard length (SL) and is based on measured voucher specimens whenever possible. However, in some cases, it is based on other specimens captured with the same methods, or in a few cases on information in the literature. Sizes are means in $\mathrm{cm}$. The regression of speed on body length utilised the average size and the average speed of each taxon, and the figure shows 1 point, based on these data, for each taxon, regardless of number of individuals measured for each.

Data from the 2 study sites (GBR and Poly) are kept separate even if the same species is involved due to differences in environments and capture methods employed at each site. For readability, the same species from 2 different sites is referred to as 2 taxa rather than 1 . 


\section{RESULTS}

Most species swam at remarkably high mean speeds, the average of which was $20.6 \mathrm{~cm} \mathrm{~s}^{-1}$ (Table 1). The fastest species (Myripristis $\mathrm{sp}$.) swam at $65.5 \mathrm{~cm}$ $\mathrm{s}^{-1}$, but this is based on only 1 individual. The fastest species for which we have replicate measurements was the acanthurid Acanthurus triostegus at $55.7 \mathrm{~cm}$ $\mathrm{s}^{-1}$. Mean speeds of more than half the species were in excess of $20 \mathrm{~cm} \mathrm{~s}^{-1}$ (Fig. 2), and 3 were greater than $40 \mathrm{~cm} \mathrm{~s}^{-1}$. Twenty-one species $(39 \%)$ swam at 10 to $19.9 \mathrm{~cm} \mathrm{~s}^{-1}$, and $20\left(37 \%\right.$ ) at 20 to $29.9 \mathrm{~cm} \mathrm{~s}^{-1}$ (Fig. 2) There was a marked taxonomic component to this (Table 2). Ephippidids were the slowest swimmers $\left(4.9 \mathrm{~cm} \mathrm{~s}^{-1}\right)$ although this is based on only 1 specimen. of 1 species. Otherwise, apogonids were the slowest swimmers, with a family average of only $6.3 \mathrm{~cm} \mathrm{~s}^{-1}$, followed by nemipterids at $10.5 \mathrm{~cm} \mathrm{~s}^{-1}$. Family average speeds of the remaining 12 families exceeded $17 \mathrm{~cm} \mathrm{~s}^{-1}$, and they exceeded $25 \mathrm{~cm} \mathrm{~s}^{-1}$ in 5 of these (acanthurids, blenniids, holocentrids, lutjanids, and microdesmids) Within families, large differences in swimming speed were common among species, with the pomacentrids, apogonids and chaetodontids the most obvious examples (Table 1).

The mean speeds of the 20 taxa (mostly species) for which we had measurements on 5 or more individuals fell into 4 broad groups based on speed (Fig. 3). The 2 Apogon species were the slowest at about $5 \mathrm{~cm} \mathrm{~s}^{-1}$. Three pomacentrids (Abudefduf septemfasciatus, Dischistodus spp. and Chrysiptera rollandi) and the nemipterid Scolopsis spp. swam at about 9 to $11 \mathrm{~cm} \mathrm{~s}^{-1}$. A large group including all 5 chaetodontids of 2 genera

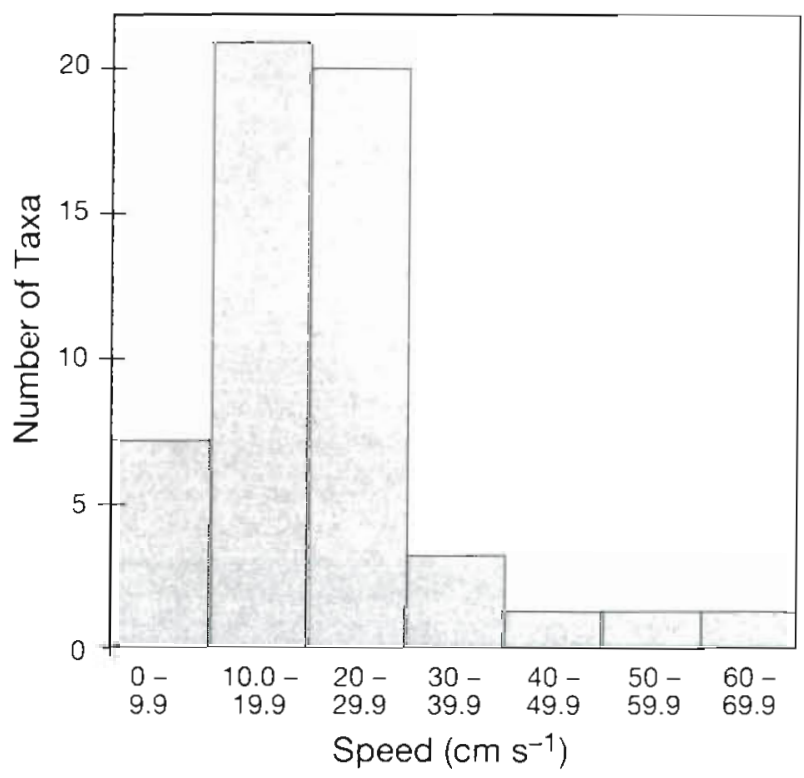

Fig 2. Frequency distribution of mean swimming speed of 54 taxa (see Table 1) of late-stage larvae of coral-reef fishes
(Chaetodon and Chelmon), the Lethrinus spp., 6 pomacentrids of 5 genera (Chromis, Chrysiptera, Dascyllus, Neopomacentrus and Pomacentrus) and the serranid Diploprion bifasciatum swam at 15 to $24 \mathrm{~cm} \mathrm{~s}^{-1}$. The acanthurid Acanthurus triostegus was the fastest by far at $56 \mathrm{~cm} \mathrm{~s}^{-1}$.

Speed of the fastest individual is perhaps the best estimate of the swimming potential of a species (Table 1). For the 36 species in which $n>1$, the average difference between the mean speed and the fastest individual was $7.4 \mathrm{~cm} \mathrm{~s}^{-1}$ (range 0.2 to $22.8 \mathrm{~cm} \mathrm{~s}^{-1}$ ). On average, the fastest individual of a species swam $44 \%$ faster (range 4 to $92 \%$ ) than the mean speed for that species. In the 2 fastest species (Myripristis sp. and Acanthurus triostegus), the fastest individual swam at $65 \mathrm{~cm} \mathrm{~s}^{-1}$, which is a slight underestimate, as these 2 fishes slowly pulled away from the divers because they could not keep pace.

If speed is expressed as $\mathrm{BL} \mathrm{s} \mathrm{s}^{-1}$, the performance of some smaller species is emphasised (Table 1). By this measure of mean speed, the 2 fastest species were a small $(0.7 \mathrm{~cm})$ pomacentrid, Chromis atripectoralis $\left(33.8 \mathrm{BL} \mathrm{s}^{-1}\right)$, and a small $(1.0 \mathrm{~cm})$ blenniid, Stanulus seychellensis (26.4 BL s$\left.{ }^{-1}\right)$, but 3 other pomacentrid species and a chaetodontid $(0.8$ to $1.4 \mathrm{~cm} \mathrm{SL})$ swam at 24. BL s $\mathrm{s}^{-1}$ or faster. Most species (31) swam at 10 to $20 \mathrm{BL} \mathrm{s}^{-1}$, and 7 swam at $>20 \mathrm{BL} \mathrm{s}^{-1}$ (Fig. 4). The fastest family average was for the Blenniidae at $26.4 \mathrm{BL} \mathrm{s}^{-1}$, but this was based on only 1 individual of 1 species. Otherwise, the fastest families were pomacanthids, pomacentrids, holocentrids, chaetodontids and acanthurids, all at $>12.7 \mathrm{BL} \mathrm{s}^{-1}$ (Table 2). The slowest families were carapidids, ephippidids and apogonids, all at $<5.8 \mathrm{BL} \mathrm{s}^{-1}$ : all others were faster than $10 \mathrm{BL} \mathrm{s}^{-1}$ (Table 2). So, irrespective of which units are used to quantify swimming speed, the ephippidids and apogonids were among the slowest families.

Although the difference in swimming speed between the fastest and slowest individual of a species was frequently large (Table 1), overall, the variation in speed around the average was not large. The 20 species for which we had measurements on 5 or more individuals had an average mean speed of $18.7 \mathrm{~cm} \mathrm{~s}^{-1}$ (Table 1, Fig. 3). For these species, the SE of mean speed was 0.8 to $5.3 \mathrm{~cm} \mathrm{~s}^{-1}$, which is 4.1 to $25 \%$ of the mean speed. In 9 species, SE was $<10 \%$ mean speed, and in only 4 was it $>20 \%$. Thus, while there is obvious potential for high variation in swimming speed, it was realised in only a few species.

If all species were pooled, there was not a significant relationship between speed and size ( speed $=1.13$ size $+18.36, R^{2}=0.06, p=0.10$ ). However, if we discounted the very long $(19.4 \mathrm{~cm})$, worm-like larva of the carapidid, which had an anguilliform style of swimming shared by no other species we studied, the relationship became sig- 
Table 1. Swimming speed of late larvae of coral-reef fishes. Sizes are mean standard lengths. GBR; Great Barrier Reef; POLY: Tuamotu Islands; Max, Min: fastest and slowest individual, SE: standard error 'Taxa that, in general, did not swim 'normally'

\begin{tabular}{|c|c|c|c|c|c|c|c|c|c|c|}
\hline \multirow[t]{2}{*}{ Species } & \multirow[t]{2}{*}{ Location } & \multirow{2}{*}{$\begin{array}{l}\text { Size } \\
(\mathrm{cm})\end{array}$} & \multirow[t]{2}{*}{$N$} & \multicolumn{4}{|c|}{ Speed $\left(\mathrm{cm} \mathrm{s}^{-1}\right)$} & \multicolumn{3}{|c|}{ Speed $\left(B L s^{-1}\right)$} \\
\hline & & & & Mean & $\mathrm{SE}$ & Max & Min & Mean & $\operatorname{Max}$ & Min \\
\hline \multicolumn{11}{|l|}{ Acanthuridae } \\
\hline Acanthurus sp. & GBR & 2.1 & 3 & 24.7 & 9.6 & 47.6 & 8.3 & 11.8 & 22.6 & 4.0 \\
\hline Acanthurus triostegus & POLY & 2.4 & 7 & 55.7 & 3.1 & 65.3 & 36.8 & 23.2 & 27.2 & 15.3 \\
\hline Naso brevirostris & POLY & 2.6 & 2 & 26.9 & 0.9 & 28.3 & 25.6 & 10.4 & 109 & 9.8 \\
\hline Naso hituratus & POLY & 5.5 & 1 & 29.5 & & & & 5.4 & & \\
\hline \multicolumn{11}{|l|}{ Apogonidae } \\
\hline Apogon spp. & GBR & 0.9 & 6 & 5.1 & 1.3 & 8.8 & 0.7 & 5.9 & 10.0 & 0.9 \\
\hline Apogon cf. cyanosoma & GBR & 1.2 & 3 & 6.5 & 1.6 & 8.8 & 2.7 & 5.4 & 7.3 & 2.2 \\
\hline Apogon cyanosoma & GBR & 1.1 & 1 & 12.8 & & & & 11.6 & & \\
\hline Apogon taensophorus & GBR & 1.0 & 3 & 1.8 & 0.7 & 3.5 & 0.9 & 1.8 & 3.5 & 0.9 \\
\hline \multicolumn{10}{|l|}{ Blenniidae } & 2.5 \\
\hline Stanulus seychellensis & GBR & 1.0 & 1 & 26.4 & & & & 26.4 & & \\
\hline \multicolumn{11}{|l|}{ Carapididae } \\
\hline $\begin{array}{l}\text { Carapini } \\
\text { Chaetodontidae }\end{array}$ & POLY & 19.4 & 1 & 20.4 & & & & 1.1 & & \\
\hline Chaetodon aureofasciatus & GBR & 1.1 & 5 & 17.9 & 3.7 & 25.5 & 3.4 & 16.3 & 23.2 & 3.0 \\
\hline Chaetodon aunga & GBR & 1.8 & 1 & 13.5 & & & & 7.5 & & \\
\hline Chaetodon auriga & POLY & 1.9 & 2 & 3.8 & 0.1 & 4.0 & 3.6 & 2.0 & 2.1 & 1.9 \\
\hline Chaetodon citrinellus & POLY & 2.8 & 2 & 24.2 & 0.7 & 25.2 & 23.3 & 8.7 & 9.0 & 8.3 \\
\hline Chaetodon plebeius & GBR & 1.0 & 11 & 24.1 & 1.7 & 31.6 & 13.1 & 24.1 & 31.6 & 13.1 \\
\hline Chaetodon rainfordi & GBR & 1.1 & 9 & 20.8 & 2.8 & 33.6 & 9.0 & 18.9 & 30.6 & 8.2 \\
\hline Chaetodon trifascialls & GBR & 1.1 & 4 & 15.4 & 3.8 & 23.3 & 4.9 & 14.0 & 21.2 & 4.5 \\
\hline Chaetodon trifasciatus & POLY & 1.1 & 6 & 20.9 & 5.0 & 39.0 & 4.9 & 19.0 & 35.5 & 4.5 \\
\hline Chelmon rostratus & GBR & 1.5 & 7 & 17.6 & 2.2 & 23.6 & 6.7 & 11.7 & 15.7 & 4.5 \\
\hline Coradion chrysozonus & GBR & 1.4 & 2 & 26.1 & 3.0 & 30.3 & 21.9 & 18.6 & 21.6 & 15.6 \\
\hline Ephippididae & & & & & & & & & & \\
\hline Platax pinnatus & GBR & 0.9 & 1 & 4.9 & & & & 5.4 & & \\
\hline Myripristis sp. & POLY & 5.5 & 1 & 65.5 & & & & 11.9 & & \\
\hline Neoniphon sammara. & POLY & 2.8 & 1 & 48.1 & & & & 17.2 & & \\
\hline Lethrinidae & & & & & & & & & & \\
\hline Lethrinus spp. & GBR & 1.8 & 11 & 19.4 & 1.2 & 27.2 & 13.8 & 10.8 & 15.1 & 7.6 \\
\hline Lutjanidae & & & & & & & & & & \\
\hline Lutjanus fulviflamma & GBR & 1.6 & 1 & 14.5 & & & & 9.0 & & \\
\hline Lutjanus carponotatus & GBR & 2.0 & 2 & 23.5 & 7.5 & 34.0 & 12.9 & 11.7 & 17.0 & 6.5 \\
\hline Caesio cuning & GBR & 2.0 & 1 & 39.7 & & & & 19.9 & & \\
\hline Caesio sp. & GBR & 2.0 & 1 & 23.3 & & & & 11.7 & & \\
\hline Microdesmidae & & & & & & & & & & \\
\hline Ptereleotris sp. & POLY & 2.3 & 2 & 28.9 & 7.0 & 38.8 & 18.9 & 12.5 & 16.9 & 8.2 \\
\hline $\begin{array}{l}\text { Ptereleotris heteroptera } \\
\text { Nemipteridae }\end{array}$ & GBR & 3.1 & 2 & 32.8 & 7.7 & 43.7 & 21.9 & 10.6 & 14.1 & 7.1 \\
\hline Scolopsis spp. & GBR & 1.0 & 10 & 10.5 & 1.9 & 18.2 & 2.5 & 10.5 & 18.2 & 2.5 \\
\hline Pomacanthidae & & & & & & & & & & \\
\hline $\begin{array}{l}\text { Pomacanthus sexstriatus } \\
\text { Pomacentridae }\end{array}$ & GBR & 1.3 & 2 & 22.2 & 2.3 & 25.5 & 18.9 & 17.1 & 19.6 & 14.6 \\
\hline Pomacentridae & & & & & & & & & & \\
\hline Abudefduf septemfasciatus & GBR & 1.2 & 5 & 10.2 & 1.9 & 16.4 & 5.1 & 8.5 & 13.6 & 4.2 \\
\hline Chromis atripectoralis & GBR & 0.7 & 25 & 23.7 & 1.0 & 36.9 & 7.8 & 33.8 & 52.7 & 11.1 \\
\hline Chromis cyanea & POLY & 0.8 & 4 & 19.1 & 4.3 & 33.1 & 9.2 & 23.9 & 41.3 & 11.6 \\
\hline Chrysiptera glauca & POLY & 1.3 & 6 & 24.4 & 5.3 & 38.8 & 7.5 & 18.8 & 29.9 & 5.8 \\
\hline Chrysiptera leucopoma & POLY & 1.4 & 2 & 34.6 & 3.7 & 39.9 & 29.4 & 24.7 & 28.5 & 21.0 \\
\hline Chrysiptera rollandi & GBR & 1.0 & 15 & 11.5 & 1.3 & 19.3 & 2.3 & 11.5 & 19.3 & 2.3 \\
\hline Dascyllus aruanus & GBR & 0.8 & 11 & 19.7 & 1.9 & 30.1 & 9.1 & 24.6 & 37.7 & 11.4 \\
\hline Dascyllus reticulatus & GBR & 0.8 & 1 & 15.3 & & & & 19.1 & & \\
\hline Dascyllus trimaculatus & GBR & 1.0 & 1 & 12.2 & & & & 12.2 & & \\
\hline Dascyllus trimaculatus & POLY & 1.0 & 1 & 12.2 & & & & 12.2 & & \\
\hline Dischistodus spp. & GBR & 0.9 & 18 & 8.7 & 0.9 & 15.1 & 2.8 & 9.6 & 16.8 & 3.1 \\
\hline Neopomacentrus azysron & GBR & 1.2 & 10 & 18.9 & 1.3 & 26.8 & 13.5 & 15.8 & 22.3 & 11.3 \\
\hline Neopomacentrus cyanomos? & GBR & 1.1 & 14 & 16.6 & 1.6 & 25.4 & 2.2 & 15.1 & 23.1 & 2.0 \\
\hline Pomacentrus amboinensis. & GBR & 1.2 & 1 & 11.8 & & & & 9.8 & & \\
\hline Pomacentrus lepidogenys & GBR & 1.3 & 10 & 22.3 & 1.1 & 26.6 & 16.0 & 17.1 & 20.5 & \\
\hline Pomacentrus moluccensis. & GBR & 1.1 & 2 & 10.7 & 0.5 & 11.5 & 9.9 & 9.7 & 10.4 & 9.0 \\
\hline Stegastes $\mathrm{sp}$ & POLY & 1.4 & 1 & 25.9 & & & & 18.5 & & \\
\hline Serranidae & & & & & & & & & & \\
\hline Diploprion bifasciatum & GBR & 2.5 & 11 & 21.8 & 1.0 & 26.4 & 16.5 & 8.7 & 10.6 & 6.6 \\
\hline Plectropomus leopardus & GBR & 1.7 & 3 & 19.2 & 1.6 & 23.0 & 16.3 & 11.3 & 13.5 & 9.6 \\
\hline Tetraodontidae & & & & & & & & & & \\
\hline Canthigaster bennett ${ }^{\circ}$ & GBR & 2.5 & 1 & 25.2 & & & & 10.1 & & \\
\hline Canthigaster valentini ${ }^{\circ}$ & GBR & 1.2 & 1 & 14.4 & & & & 12.0 & & \\
\hline
\end{tabular}


Table 2 Family average values for swimming speed of the late larvae of coralreef fishes

\begin{tabular}{|c|c|c|c|c|c|c|c|}
\hline \multirow{2}{*}{ Family } & \multirow{2}{*}{$\begin{array}{c}\text { No. of } \\
\text { taxa }\end{array}$} & \multicolumn{3}{|c|}{ Speed $\left(\mathrm{cm} \mathrm{s}^{-1}\right)$} & \multicolumn{3}{|c|}{ Speed $\left(B L s^{-1}\right)$} \\
\hline & & Average & $\operatorname{Max}$ & Min & Average & $\operatorname{Max}$ & Min \\
\hline Acanthuridae & 4 & 28.2 & 55.7 & 24.7 & 12.7 & 23.2 & 5.4 \\
\hline Apogonidae & 5 & 6.3 & 12.8 & 1.8 & 5.8 & 11.6 & 1.8 \\
\hline Blenniidae & 1 & 26.4 & & & 26.4 & & \\
\hline Carapididae & 1 & 20.4 & & & 1.1 & & \\
\hline Chaetodontidae & 10 & 18.4 & 26.1 & 3.8 & 14.4 & 24.1 & 3.8 \\
\hline Ephippididae & 1 & 4.9 & & & 5.4 & & \\
\hline Holocentridae & 2 & 56.8 & 65.5 & 48.1 & 14.6 & 17.2 & 11.9 \\
\hline Lethrinidae & 1 & 19.4 & & & 10.8 & & \\
\hline Lutjanidae & 4 & 25.2 & 39.7 & 14.5 & 13.1 & 19.9 & 9 \\
\hline Microdesmidae & 2 & 30.8 & 28.9 & 32.8 & 11.6 & 12.5 & 10.6 \\
\hline Nemipteridae & 1 & 10.5 & & & 10.5 & & \\
\hline Pomacanthidae & 1 & 22.2 & & & 17.1 & & \\
\hline Pomacentridae & 17 & 17.5 & 34.6 & 8.7 & 16.8 & 33.8 & 8.5 \\
\hline Serranidae & 2 & 20.5 & 21.8 & 19.2 & 10.0 & 11.3 & 8.7 \\
\hline Tetraodontidae & 2 & 19.8 & 25.2 & 14.4 & 11.0 & 10.1 & 12 \\
\hline
\end{tabular}

nificant with $\mathrm{R}^{2}=0.43$ (Fig. 5). If attention was confined to the size range over which we had good coverage (i.e. 0.8 to $3.1 \mathrm{~cm} \mathrm{SL),} \mathrm{the} \mathrm{relationship} \mathrm{was} \mathrm{still} \mathrm{significant,}$ and with similar slope (speed $=10.2$ size $+4.5, \mathrm{p} \ll 0.01$ ), but $R^{2}$ decreased to 0.35 . This reflects the variability in speed at size, particularly among the smaller $(<2 \mathrm{~cm} \mathrm{SL})$ species. Only 2 families-Pomacentridae and Chaetodontidae - had enough species represented to justify independent analysis. In neither was the relationship between speed and size significant $\left(\mathrm{R}^{2}=0.14\right.$ and 0.01 , respectively, both $\mathrm{p}>0.10$ ). However, any relationship that might exist would be very difficult to detect because of the narrow range in size of the species in these 2 families (Table 1 ).

Included in the above analyses are data from 6 species which usually did not swim in a 'normal' way (marked with - in Table 1). For each of these species, 1 or 2 individuals did swim without abnormal behaviour in the presence of divers, and it is these few individuals that provided the included data. The average speed of these 6 species was $20.8 \mathrm{~cm} \mathrm{~s}^{-1}\left(11.3 \mathrm{BL} \mathrm{s}^{-1}\right)$ compared with a mean of $20.6 \mathrm{~cm} \mathrm{~s}^{-1}$ $\left(13.7 \mathrm{BL} \mathrm{s}^{-1}\right)$ for all 50 taxa. Therefore, there is no reason to suspect that the speeds of the amenable individuals of the 6 species that were not usually amenable to our approach were anything other than representative.

\section{DISCUSSION}

When making behavioural observations such as those reported here, it is possible that the presence of the observer leads to bias or unnatural behaviour. In the present study, all indications were that this was not a serious problem for most species (see 'Methods'), and although the swimming speed data are clearly collected under more natural conditions than those obtainable in the laboratory, the degree of bias cannot

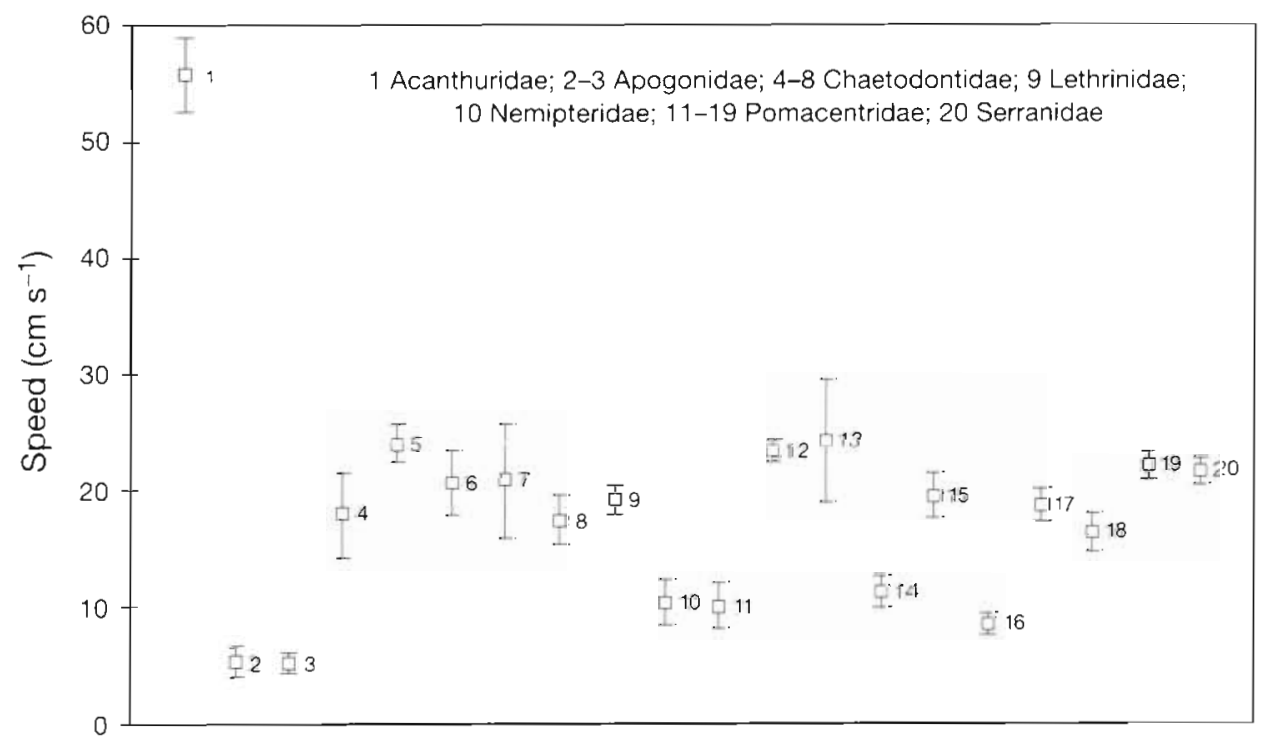

Fig. 3. Mean swimming speed (and standard error) for the late-stage larvae of 20 species for which 5 or more individuals were measured. The key gives the families. Species: 1, Acanthurus triostegus; 2, Apogon spp.; 3, Apogon trimaculatus; 4, Chaetodon aureofasciatus; 5 , Chaetodon plebeius; 6 , Chaetodon rainfordi; 7 . Chaetodon trifasciatus; 8 , Chelmon rostratus; 9 , Lethrinus spp.; 10, Scolopsis spp.; 11, Abudefduf septemfasciatus; 12, Chromis atripectoralis; 13, Chrysiptera glauca; 14, Chrysiptera rollandi; 15. Dascyllus aruanus; 16. Dischistodus spp.; 17. Neopomacentrus azysron; 18, Neopomacentrus cyanomos?; 19, Pomacentrus lepidogenys; 20 , Diploprion bitasciatum. See Table 1 for other details on these taxa 


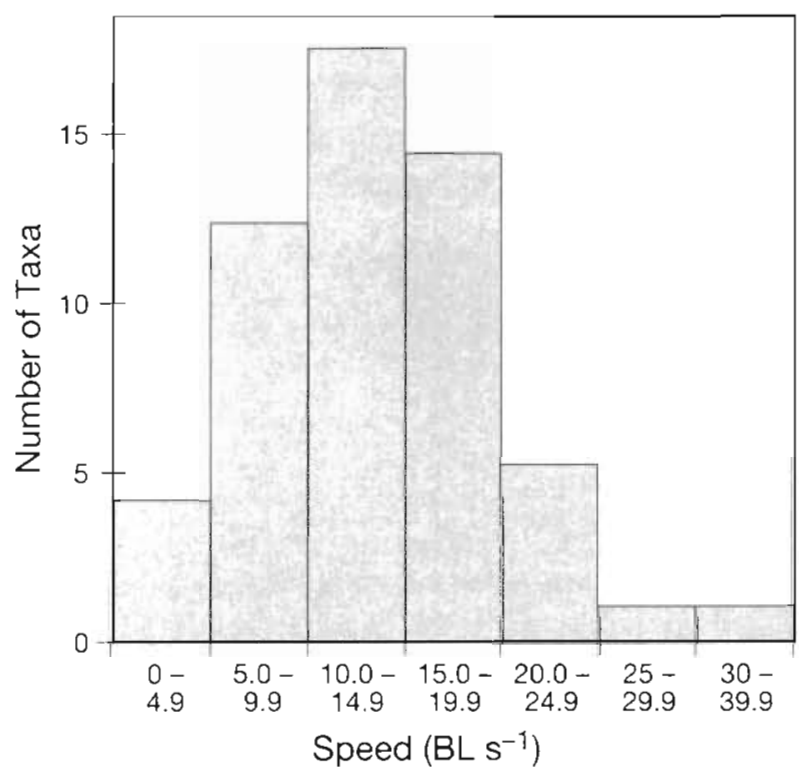

Fig. 4. Frequency distribution of mean swimming speed of 54 taxa of late-stage larvae of coral-reef fishes. Same taxa as Fig. 2

be determined rigorously in the pelagic environment with such small animals. Technological advances (e.g. Jaffe et al. 1995) should soon enable in situ swimming speeds of individual fish larvae to be determined without the immediate presence of an observer. Until then, observations on carefully chosen species by divers, such as those presented here, are the best, and seemingly a valid, measure of the swimming abilities of coral-reef fish larvae.

The in situ speeds reported here are remarkably high for such small fishes. The faster larvae can match the maximum sustained speeds of fully equipped
SCUBA divers, and in a few cases, the larvae slowly pulled away from the divers in spite of the latter's best efforts. The speeds of the larvae are even more impressive when viewed as $\mathrm{BL} \mathrm{s} \mathrm{s}^{-1}$. Our observations of swimming speed took place over $10 \mathrm{~min}$ periods, and although we cannot be sure that these speeds can be maintained over longer periods, the laboratory studies of Stobutzki \& Bellwood $(1994,1997)$ show that late larvae of coral-reef fishes can maintain speeds of $13.5 \mathrm{~cm} \mathrm{~s}^{-1}$ for days at a time. Thus, we are confident the speeds we report here are representative of cruising, rather than burst, performance.

Most species that we studied are capable of swimming at speeds far in excess of cruising speeds reported for larvae of temperate fishes in the laboratory. Blaxter (1986, p. 104) reviewed cruising speed data on fish larvae of similar size to those we studied, and concluded that 'speeds of about $1 \mathrm{BL} \mathrm{s}^{-1}$ are found for larvae moving freely in tanks or during rearing experiments and speeds of $3 \mathrm{BL} \mathrm{s} s^{-1}$ or more when larvae are subjected to currents in a flume:. However, he noted that 2 species had better performance: largemouth bass and chub mackerel larvae swam at about 4 to $5 \mathrm{BL} \mathrm{s}^{-1}$, and he wondered why these 2 'perform so well' [Meng (1993) obtained similar values for striped bass]. The average coral-reef fish species in our experiments swam at $13.8 \mathrm{BL} \mathrm{s}^{-1}$, and some were nearly twice this fast. Only the slowest coral-reef species swam at the 4 to $5 \mathrm{BL}^{-1}$ that Blaxter found surprisingly high. Further, cruising speeds of reef-fish larvae are as fast as burst (or, escape) speeds of temperate larvae (Williams et al. 1996). In part, this is a result of developmental differences-most larvae of coral-reef fishes have fully developed fins at a smaller size than temperate taxa, even though they retain the specialisa-
Fig. 5. Relationship of swimming speed to size (standard length) in late-stage larvae of coral-reef fishes. Each point represents mean values for a single taxon as listed in Table $1(n=53)$. The carapidid is omitted (see text). If the points at $5.5 \mathrm{~cm}$ standard length (Myripristis $\mathrm{sp}$. and Naso lituratus) are omitted, the resulting regression line is: speed $=10.19$ length +4.49 , $\mathrm{r}^{2}=0.35$

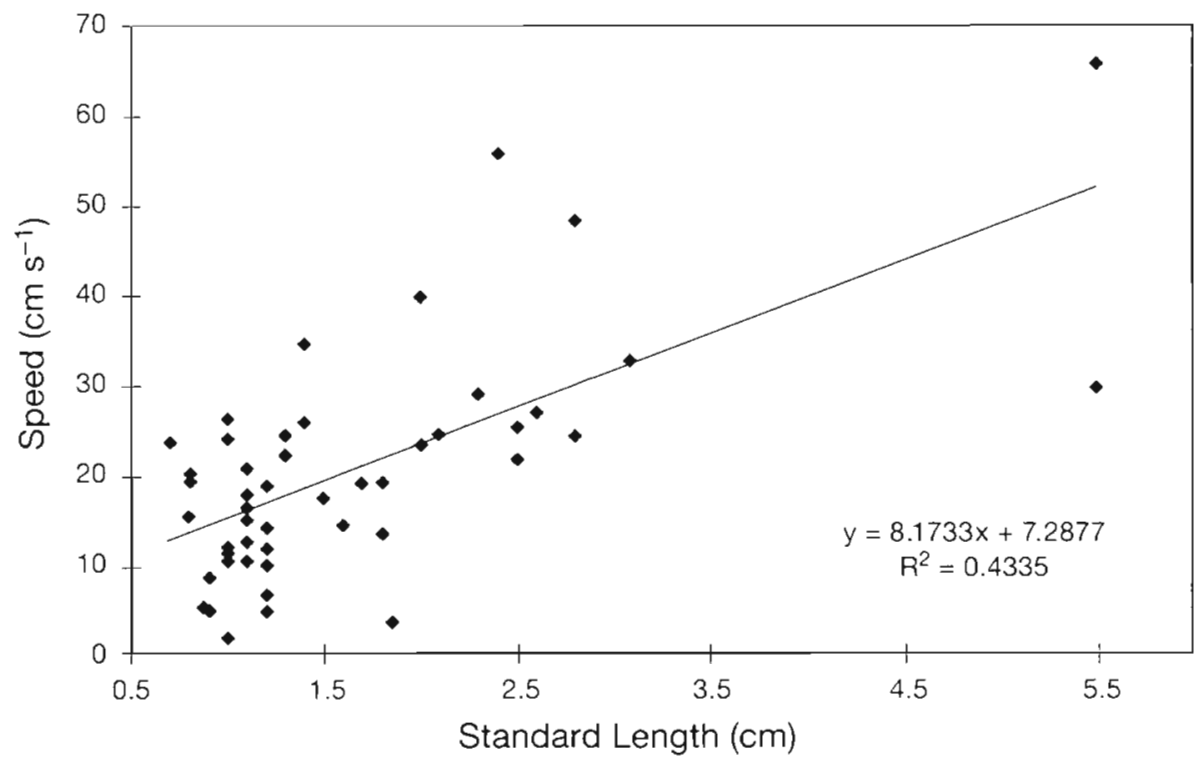


tions for pelagic life (e.g. long, ornamented fin spines, and extensive spination on the head) that lead to them being regarded as larvae (Leis \& Trnski 1989). However, there is also a strong phylogenetic component to this. Like most coral-reef fishes, nearly all the taxa studied here are members of the suborder Percoidei of the order Perciformes (Choat \& Bellwood 1991), - whereas most of the taxa reviewed by Blaxter (1986) from temperate waters are of the orders Clupeiformes (e.g. herring), Gadiformes (e.g. cod) or Pleuronectiformes (e.g. plaice). It is worth noting that the bass and mackerel that impressed Blaxter are also perciform fishes, so larvae of perciform fishes may be superior swimmers. However, Miller et al. (1988) obtained results similar to Blaxter's (about $1 \mathrm{BL} \mathrm{s}^{-1}$ cruising speed, about $7 \mathrm{BL} \mathrm{s}^{-1}$ burst speed) in a review of 72 species, 22 of which were Perciformes. Another factor may be that many laboratory-based studies use laboratory-reared larvae, which may not have the vigour of wild conspecifics (Duthie 1987, Cobb et al. 1989). Swimming may be more efficient at tropical temperatures $\left(24\right.$ to $\left.31^{\circ} \mathrm{C}\right)$ than at those found in temperate seas $\left(<15^{\circ} \mathrm{C}\right.$; Wardle 1975$)$. Finally, it might be that larvae of coral-reef fishes are better swimmers because swimming performance is more favoured in coral-reef systems. The selective pressures on a pelagic stage that must leave open water to find a small reef target in a large, tropical ocean are undoubtedly very different than those on a pelagic larval stage that either remains pelagic (e.g. anchovy) or has a proportionally larger target at settlement (e.g. cod). In contrast to temperate fish larvae, larvae of some temperate invertebrates swim at speeds in the same range as those we observed for larvae of coral-reef fishes. Shanks (1995) reports speeds of 9.5 to $46 \mathrm{~cm} \mathrm{~s}^{-1}$ for larvae of a variety of crabs and lobsters. It is not clear why swimming performance of larvae of temperate invertebrates and fishes should differ.

The speeds reported here are by no means maximum speed for these small pelagic fishes. During our speed measurement sessions, we frequently observed the larvae examining food particles and feeding, thus slowing their average cruising speed. In addition, they often did not swim in a straight line at small scales, rather they manoeuvred around clumps of marine snow, salps or jellies, also resulting in a somewhat underestimated speed as measured by our methods. Some individuals engaged in stop-and-go behaviour, often for no apparent reason, but frequently due to the presence of potential predators. Also, much higher speeds were observed when we attempted to recapture a fish at the end of the observation period, although these might be considered burst, rather than sustained, speeds. Further, for the late larvae of 3 pomacentrid species, the maximum speed the so- called 'critical speed') that could be maintained for 5 min in a forced swimming situation in a laboratory flume (Stobutzki \& Bellwood 1994) was 3 to 5 times greater than our in situ speed measurements on the same taxa (although within the range we found for other taxa). Interestingly, Blaxter (1986) noted a similar (3-fold) difference between flume-based and 'unforced' speeds. Therefore, the speeds at which the larvae choose to swim in situ are less than the maximum of which they are capable, but apparently represent what the larvae are really doing in the field.

In the Lizard Island Region of the GBR Lagoon, ambient average current speeds are 10 to $15 \mathrm{~cm} \mathrm{~s}^{-1}$ (Frith et al. 1986, Leis 1986). Current speeds near Poly are unknown. Therefore, nearly all the species for which we have measurements are capable of speeds faster than the average ambient flow and have the potential for considerable control over their position and distribution (i.e. they are effective swimmers). For example, dispersal models could hardly regard these larvae as passive. It is important to remember, however, that the speed measurements reported here are for 1 to $5 \mathrm{~cm}$ long larvae, near the end of their pelagic period.

Although we found an overall positive relationship between size of larvae at the end of the pelagic stage and swimming speed, the relationship was not very strong. Further, it was not significant within the 2 families for which we had the most data. Therefore, the relationship is of limited use for predictive purposes. It is important to emphasise that we did not compare speed to size at different developmental stages. This means, for example, it would be inappropriate to use the relationship reported here to predict the swimming speed of different developmental stages (usually of different sizes) within or among taxa.

The size range (or developmental stages) and time period over which larvae are effective swimmers capable of controlling position and distribution remains unknown, but there are certainly ontogenetic changes in swimming ability. At hatching, larvae are not very strong swimmers, while at the end of the pelagic stage, they are. Our preliminary data on in situ swimming abilities of larvae mid-way through development can help determine when 'effective swimming' begins. In 5 smaller ( 0.6 to $0.8 \mathrm{~cm} \mathrm{SL}$ ), less developed pomacentrid larvae (probably genus Pomacentrus) the average speed was $4.6 \mathrm{~cm} \mathrm{~s}^{-1}$ (range 2.5 to 6.8 ), or $6.1 \mathrm{BL} \mathrm{s}^{-1}$ (unpubl. data). This is about 25 to $50 \%$ mean speed of settlement stage Pomacentrus larvae and indicates that larvae about mid-way through the pelagic period are reasonably strong swimmers, although they are not yet effective swimmers capable of speeds greater than average ambient currents. Stobutzki \& Bellwood (1994) showed that in 3 pomacentrid species swim- 
ming speed of settlement-stage individuals was greater than of recently settled juveniles, indicating that rapid ontogenetic changes in swimming ability may coincide with ecological transitions.

A few general statements about swimming performance are possible. Overall, swimming speeds are only moderately variable in terms of SE among individuals of the same species. This is perhaps surprising given the potential speeds demonstrated by the fastest individual of each species. So far, swimming speeds for relatively few species are known but even at this early stage, large differences among species in swimming performance are evident, and families appear to differ in the amount of variation present in their included taxa. The differences in speed among taxa may relate to the dispersal strategy of the species involved, but not enough is known to try to relate the two. All our measurements of swimming speed were made during daylight. It is not known how swimming speeds might differ at night.

How representative are the taxa we studied? All GBR species were captured by a light trap, a highly selective aggregation device that requires the fish to swim to, and actively enter, a chamber (Choat et al. 1993). It might be, therefore, that the light trap selects species or individuals that are superior swimmers compared to taxa or individuals that do not enter the trap. If this were true, taxa captured by other methods might swim more slowly. The average speed of the 38 taxa captured by light trap was $17.5 \mathrm{~cm} \mathrm{~s}^{-1}$, whereas the average speed of the 15 taxa captured by the presumably less selective hoa (crest) net was $29.3 \mathrm{~cm} \mathrm{~s}^{-1}$. Therefore, the taxa captured by light trap were certainly not faster, but this comparison is confounded by differences in location, and few species were common to both samples. The best that can be said at present is there is no support for the notion that 'light-trap taxa' are better swimmers. It is premature to generalise to other taxa we did not study, but given the wide range of species, genera and families we did examine, it appears that good swimming performance is widespread among larvae of coral-reef fishes.

From the speed data presented here, late larvae of coral-reef fishes have the potential to cover reasonably large distances in short periods (e.g. at $30 \mathrm{~cm} \mathrm{~s}^{-1}$, a larva covers $180 \mathrm{~m}$ during a $10 \mathrm{~min}$ 'swimming session', or, about $1 \mathrm{~km} \mathrm{~h}^{-1}$ ) and at speeds in excess of ambient current speeds. Therefore, if they have the ability to detect a reef and orientate their swimming toward it, they clearly have the swimming ability to reach the reef from distances up to several $\mathrm{km}$ in several hours. Stobutzki \& Bellwood (1997) have shown that some of these small fishes have the stamina to swim, non-stop, for a number of days. All larvae tested by Stobutzki \& Bellwood (1997) were forced to swim in the laboratory at $13.5 \mathrm{~cm} \mathrm{~s}^{-1}$, a speed slower than we observed in situ for many species. Therefore, it is possible that even greater estimates of stamina would be obtained at other speeds if it is assumed that larvae in situ select the optimal speed at which to swim. In any case, most or all of the GBR shelf (depending on location) would be within range of the late larvae of most of the species we tested. Similarly, off oceanic islands, larvae up to $20 \mathrm{~km}$ from shore could reach the island with less than $24 \mathrm{~h}$, if the fish swam in the right direction. Evidence for detection and orientation is as yet limited (Leis et al. 1996) and applies only over 1 to $2 \mathrm{~km}$, but it does suggest that settlement-stage larvae of reef fishes have the potential to have considerable control over which reef they settle upon, even if they are a substantial distance from it. It is important, nonetheless, to keep in mind that the substantial swimming performance we have documented could either be used to keep larvae near a natal reef, or to increase their dispersal from it. Good swimming performance is a necessary component of active self-recruitment, but is not sufficient.

More measurements of swimming speeds of a wider variety of species and developmental stages are needed to gain a satisfactory appreciation of the swimming capabilities of larvae of coral-reef fishes. However, these first measurements of swimming speed in situ reveal that reef-fish larvae are surprisingly strong swimmers with the capability to cover impressively large distances quickly. This capability must be taken into account in any attempt to understand or model dispersal during the pelagic stage.

Acknowledgements. Foremost, we thank the people who dived with us to help collect these data: M. Emslie. A. Hay, R. Kelly, A. Lo-Yat, P. Romans, T Trnski and C. Wellington. A. Lo-Yat and P. Romans shared their hoa-net catches and temperature data with us; M. McCormack and I. Stobutzki shared their light-trap catches with us, and the latter provided information in advance of publication. The excellent staff at the Lizard Island Research Station and EVAAM Rangiroa made our work possible and our stays enjoyable. This work was supported by Australian Research Council Grant A19530997 to J.M.L. The work at Rangiroa was also supported by DIST grant $94 / 2743$ to J.M.L and funding supplied by EPHE during J.M.L.'s tenure as visiting Professor at EPHE, Université de Perpignan. Many thanks to René Galzin who organised all. S. Bullock assisted editorially, and $\mathrm{H}$. Sweatman constructively criticised the manuscript. C. Bento supplied Fig. 1 This is a contribution from the Lizard Island Research Station and EPHE-CRIOBE

\section{LITERATURE CITED}

Blaxter JHS (1986) Development of sense organs and behaviour of teleost larvae with special reference to feeding and predator avoidance. Trans Am Fish Soc 115:98-114

Choat JH, Bellwood DR (1991) Reef fishes: their history and evolution. In: Sale PF (ed) The ecology of fishes on coral 
reefs. Academic Press, San Diego, p 39-68

Choat JH, Doherty PJ, Kerrigan BA, Leis JM (1993) A comparison of towed nets, purse seines and light aggregation devices for sampling larvae and pelagic juveniles of coral reef fishes. Fish Bull US 91:195-209

Cobb JS, Wang D, Campbell DB, Rooney P (1989) Speed and direction of swimming by postlarvae of the American lobster Trans Am Fish Soc 118:82-86

Doherty PJ (1987) Light traps: selective but useful devices for quantifying the distributions and abundances of larval fishes. Bull Mar Sci 41:423-431

Dufour $V$ (1994) Colonization of fish larvae in lagoons of Rangiroa (Tuamolu Archipelago) and Moorea (Society Archipelago). Atoll Res Bull 416:1-12

Duthie GG (1987) Observations of poor swimming performance among hatchery-reared rainbow trout, Salmo gairdneri. Environ Biol Fish 18:309-311

Frith CA, Leis JM, Goldman B (1986) Currents in the Lizard Island Region of the Great Barrier Reef Lagoon and their relevance to potential movements of larvae. Coral Reefs 5:81-92

Jaffe JS, Reuss E, McGehee D, Chandran G (1995) FTV: a sonar for tracking macrozooplankton in three dimensions. Deep Sea Res 42:1495-1512

Leis JM (1986) Vertical and horizontal distribution of fish larvae near coral reefs at Lizard Island, Great Barrier Reef. Mar Biol 90:505-516

Leis JM (1991) The pelagic phase of coral reef fishes: larval biology of coral reef fishes. In: Sale PF (ed) The ecology of fishes on coral reefs. Academic Press, San Diego, p $183-230$

Editorial responsibility: George Humphrey (Contributing Editor), Sydney, Australia
Leis JM, Sweatman HPA, Reader SE (1996) What the pelagic stages of coral reef fishes are doing out in blue water: daytime field observations of larval behavioural capabilities. Mar Freshwat Res 47:401-411

Leis JM, Trnskı $\Upsilon$ (1989) The larvae of Indo-Pacific shorefishes. New South Wales University Press, Sydney and University Press of Hawaii. Honolulu

Markle DF, Olney JE (1990) Systematics of the pearlfishes (Pisces: Carapidae). Bull Mar Sci 47:269-410

Miller TJ, Crowder LB, Rice JA, Marschall EA (1988) Larval size and recruitment mechanisms in fishes: toward a conceptual framework. Can J Fish Aquat Sci 45:1657-1670

Meng L (1993) Sustainable swimming speeds of striped bass larvae. Trans Am Fish Soc 122:702-708

Sale PF (1991) The ecology of fishes on coral reefs. Academic Press, San Diego

Shanks AL (1995) Orientated swimming by megalopae of several eastern North Pacific crab species and its potential role in their onshore migration. J Exp Mar Biol Ecol 186:1-16

Stobutzki IC, Bellwood DR (1994) An analysis of the sustained swimming abilities of pre-and post-settlement coral reef fishes. J Exp Mar Biol Ecol 175:275-286

Stobutzki IC, Bellwood DR (1997) Sustained swimming abilities of the late pelagic stages of coral reef fishes. Mar Ecol Prog Ser 149:35-41

Wardle CS (1975) Limit of fish swimming speed. Nature 255: $725-727$

Williams PC, Brown JA, Gotceitas V, Pepin P (1996) Developmental changes in escape response performance of five species of marine larval fish. Can J Fish Aquat Sci 53: $1246-1253$

Submitted: April 11, 1997; Accepted: September 17, 1997 Proofs received from author(s): November 17, 1997 